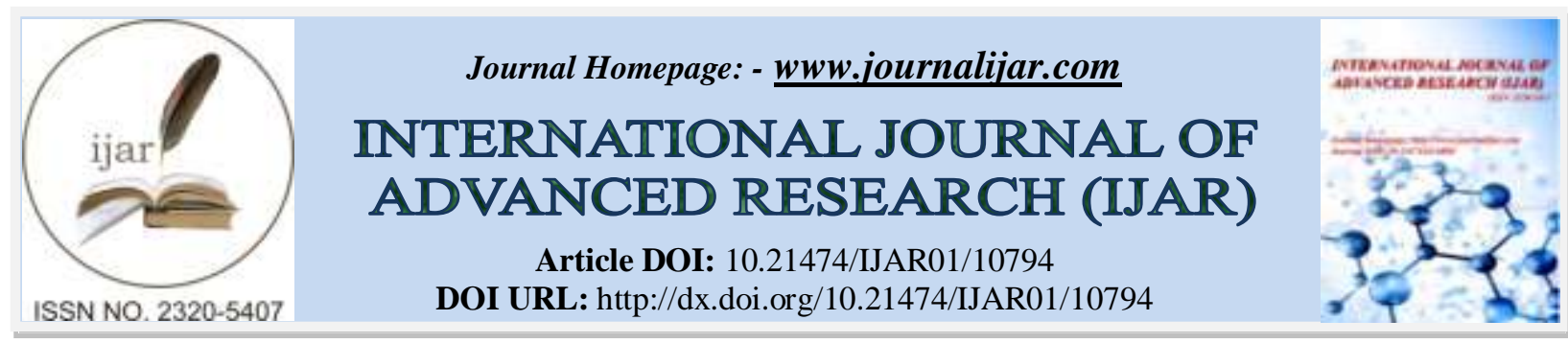

RESEARCH ARTICLE

\title{
OCCURRENCE OF HETERODOXUS SPINIGER (INSECTA: PHTHIRAPTERA: AMBLYCERA: BOOPIDAE) ON THE DOGS OF ODISHA
}

\author{
Aftab Ahmad ${ }^{1}$, Neelima Gupta ${ }^{2}$ and A.K. Saxena ${ }^{3}$ \\ 1. Estuarine Biology Regional Centre, ZSI, Gopalpur, Ganjam Odisha India. \\ 2. Chhatrapati Shahu Ji Maharaj University, Kanpur, India. \\ 3. Govt. Raza P.G. College, Rampur U.P. India.
}

\section{Manuscript Info}

Manuscript History

Received: 10 February 2020

Final Accepted: 12 March 2020

Published: April 2020

Key words:-

Amblycera, Heterodoxus Spiniger,

Phthiraptera, Insecta

\section{Abstract}

Out of the two species of biting lice known to parasitize the dog, Canis familiaris, one species, Heterodoxus spiniger (Enderlein, 1909) has been collected for first time from aforesaid host in Ganjam district of Odisha. All the collected specimens contained red contents compatible with host blood in their crops. The morphological features of $H$. spiniger have been noted with the help of LM as well as SEM.

Copy Right, IJAR, 2020,. All rights reserved.

\section{Introduction: -}

Two species of biting lice one ischnoceran, Tricodectes canis and one amblyceran, Heterodoxus spiniger (Enderlein, 1909) are known to parasitize the dog, Canis familiaris Linn. 1758 (Price et al. 2013). Both the species are haematophagus in nature (Price and Graham, 1997). H. spiniger (Enderlein, 1909) is very active fast running louse, generally found at very proximal end of hair shaft (near the skin), in posterior dorsal region of the body (Roberts and Janoy, 2000). Out of the twenty-four known species of Heterodoxus Le Souef \& Bullen, 1902 only H. spiniger (Enderlein, 1909) occurs on dog Canis familiaris.

This species reportedly occurs in all the continents (Bermudez \& Miranda 2011; Jittapalapong et al. 2008; Keler, 1971; Norhidayu et al. 2012; Plomley 1939; Price and Graham, 1997; Sultan and Khalafalla, 2014; Torres and Figueredo 2007; Troyo et al. 2012; Venezal et al. 2012; Zlotorzycka et al. 1995). Zlotorzycka and Modrzejewska, 1992 have recorded some surface ultra-structure of the louse. The detailed description of male genitalia in lice and their relatives and phylogenetic implication given by Yoshizawa and Johnson (2006). The egg morphology of the louse has been noted by Tyagi et.al. 2009. Tyagi et al. 2011 have also noted the prevalence of louse in Indian locality.

The present report furnishes information on the occurrence and morphological features of louse, H. spiniger (Enderlein, 1909) collected from Narayanpur, District Ganjam Odisha.

\section{Material and Methods:-}

The louse load of four adult dogs and six puppies were screened with a fine tooth comb for ectoparasites with the aid of hand lens fitted with circular light. Samples were collected and transferred to $70 \%$ alcohol. On a later date, entire louse load was separated stage wise and sex wise under stereozoom trinocular microscope. For light microscopic study, specimens were macerated with $10 \% \mathrm{KOH}$, washed with distilled water, treated with acidic 
acid, dehydrated in ethanol series, cleared in Xylene and mounted as described by Price and Graham, 1997. For SEM study, specimens were fixed in $2.5 \%$ Gluteraldehyde, post fixed in $0.25 \mathrm{M}$ Phosphate buffer, critically dried, arranged on metal stub, covered with double sided cello tape, gold coated in Neo Coater 100-240V and examined under JCM-6000 Scanning Electron Microscope.

\section{Result and Discussion:- \\ Type host: \\ Canis familiaris, Linn. 1758}

\section{Materials examined:}

Eight adult females, ten adult males collected by the first author from the Narayanpur, District Ganjam, Odisha, India (Latitude19 $15^{\prime} 42.8^{\prime \prime} \mathrm{N}$ Longitude 84 53'56.8” E) in 2019 and are deposited in the Museum of Estuarine Biology Regional Centre, ZSI, Gopalpur, Odisha

\section{Diagnostic characters:}

On the basis of following morphological characteristics the specimen was observed as H. spiniger (Enderlein, 1909) belonging to the genus Heterodoxus, Le Souef \& Bullen, 1902 and family Boopidae, Mjoberg, 1910.

The adult male (Plate I, Fig.1A), H. spiniger (Enderlein, 1909) is dark brown in colour and 2.68 m.m. length. The head of H. spiniger (Enderlein, 1909) is sub-triangular. The anterior margin of the head is rounded and posterior margin slightly concave. Post ocular emerginations absent. Temporal lobes acutely rounded. Two postpalpal process occur behind the maxillary palp on the ventral side of the head. The labrum lies close to anterior edge of clypeus and turned inside. Four segmented maxillary palpi are located in the anterior part of the head that are slender in shape. The antennary fossae consist of two parts, the anterior basin with antenna, and posterior large and empty basin behind the deep transverse groove. The first two segments of antennae prominently protrude from antenna fossae. The second segments of antenna are nearly round, in distal part with quite numerous protuberances. The mandible by and large remains hidden under hypopharyngeal sclerite. The labial palpi and anterior part of labium bear several sensillae. The prothorax narrower than the head while the rest part of the thorax is longer than the head. The abdomen is long and oval. Six pair spiracles present on the dorsal side of the abdomen. A thin and long hair protruding from the opening of the spiracles. The setae on abdominal segments II-IX as follows-II-tergal-11-13, sternal-4-7 and pleural-4; III- tergal-10-15, sternal-9-11 and pleural-4; IV-tergal-10-15, sternal-11-19 and pleral-5; V-tergal-17-23, sternal-14-21 and pleural-7; VI-tergal-17-20, sternal-15-23 and pleural-7; VII-tergal-14-23, sternal15-27 and pleural-8; VIII-tergal-11-18, sternal-12-15 and pleural-8; IX tergal-10, sternal 9-10 and pleural-6. In caudal part of the first three abdominal pleurites there are rounded openings of magnitude, resembling spiracles. Adjacent surfaces between neighboring pleurites bear triangular spines directed laterally. The claws are not smooth but have thick, transverse and undulated furrows, their endings being curved. Vesical equipped with a pair of spine (devoid of denticulations) and covered to IVth to IXth abdominal segments.

The adult female (Plate I, Fig. B) lice of H. spiniger (Enderlein, 1909) is 2.78 m.m. in length and dark brown in colour. The Margin of head is sub-triangular considerably thickened and chitinized. The mandibles are strongly chitinized, notched, sickle shaped ending with denticles and partly overlapping. The clypeus is separated from the remaining part of the head by an undulating suture. The thorax is longer and narrower than the head. The prothorax and pterothorax are similar in width but the latter is slightly longer than prothorax. Prosternum bear 01 setae and metasternum bear two setae respectively. The $I^{\text {st }}$ pair of legs is reduced. The setae are arranged in a row like comb on the legs. All claws are thin and short. The abdomen is composed of IX segments. The setae on abdominal segments II-IX as follows-tergal-II-10-14, sternal-4-7 and pleural-0; III-tergal-10-15, sternal-10-16 and pleural-4; IV tergal-14-17, sternal-12-21 and pleural-4-6; V -14-21, sternal-17-21 and pleural-3-6; VI tergal-11-23, sternal-17-23 and pleural-6; VII-tergal-11-21, sternal-23-27 and pleural-8; VIII tergal-10-14, sternal-12-17 and pleural-7; IXtergal-8-10, sternal-12-16 and pleural-6.

The posterior end of the abdomen is hollow and there are no setae. The abdomen of female has almost all sternites rectangular with the exception of trapezium like VIIIth. The surroundings of the spiracles, in abdominal region are always lighter than the rest of the body. Female genitalia are broadly rounded at the terminal end of abdomen. Genital papilla clearly rounded in the last abdominal segment. Vulval margin nearly straight, smooth and membranous with 7-10 marginal setae on each side. 
Morphological characteristics of the specimens collected from the dogs, Canis familiaris Linn. 1758 district Ganjam of Odisha resemble to description given by Keler, 1971 and Emerson and Price, 1975 except minor differences in setal counts and body measurements. Like other members of the Boopidae, Mjoberg, 1910, the ventral side of the head of louse is characterized with the presence of a pair of post palpal spine growing immediately behind the maxillary palps. Aforesaid process might help the louse in abrashing skin to make blood pool, to imbibe the blood. All the specimens of $H$. spiniger (Enderlein, 1909) collected during the present study contained red contents compatible with host blood in their crops. It may be noted that the haematophagus nature of certain amblyceran Phthiraptera is a great concern to parasitologist/Veterinarian. They do not only affect the health productivity and behavior of their hosts but may also act as reservoir and transmitter of infectious disease (Price and Graham, 1997). It may be noted that dog louse, H. spiniger (Enderlein, 1909) can act as intermediate host of a tape worm, Dipylidium caninum and also a filarial worm, Dipetelonema reconditum (Price and Graham, 1997; Robert and Janovy, 2000). The tape worm, D. caninum infests both dogs and humans (by accidental infection during petting of the dogs). Thus, the occurrence of H. spiniger (Enderlein, 1909) in Odisha deserves further investigation (population level) to make the public pet owner aware of potential transmission of zoonotic parasites.

Table 1:- Dimension (in mm.) of Heterodoxus spiniger.

\begin{tabular}{|l|l|l|l|l|}
\hline Parts of body & \multicolumn{2}{l|}{ Male $(\mathbf{n}=\mathbf{1 0})$} & Female $(\mathbf{n}=8)$ & Width \\
\hline & Length & Width & Length & 0.56 \\
\hline Head & 0.42 & 0.60 & 0.44 & 0.57 \\
\hline Thorax & 0.62 & 0.58 & 0.59 & 1.05 \\
\hline Abdomen & 1.64 & 1.04 & 1.75 & - \\
\hline Total & 2.68 & - & 2.78 & \multicolumn{2}{l|}{} \\
\hline
\end{tabular}
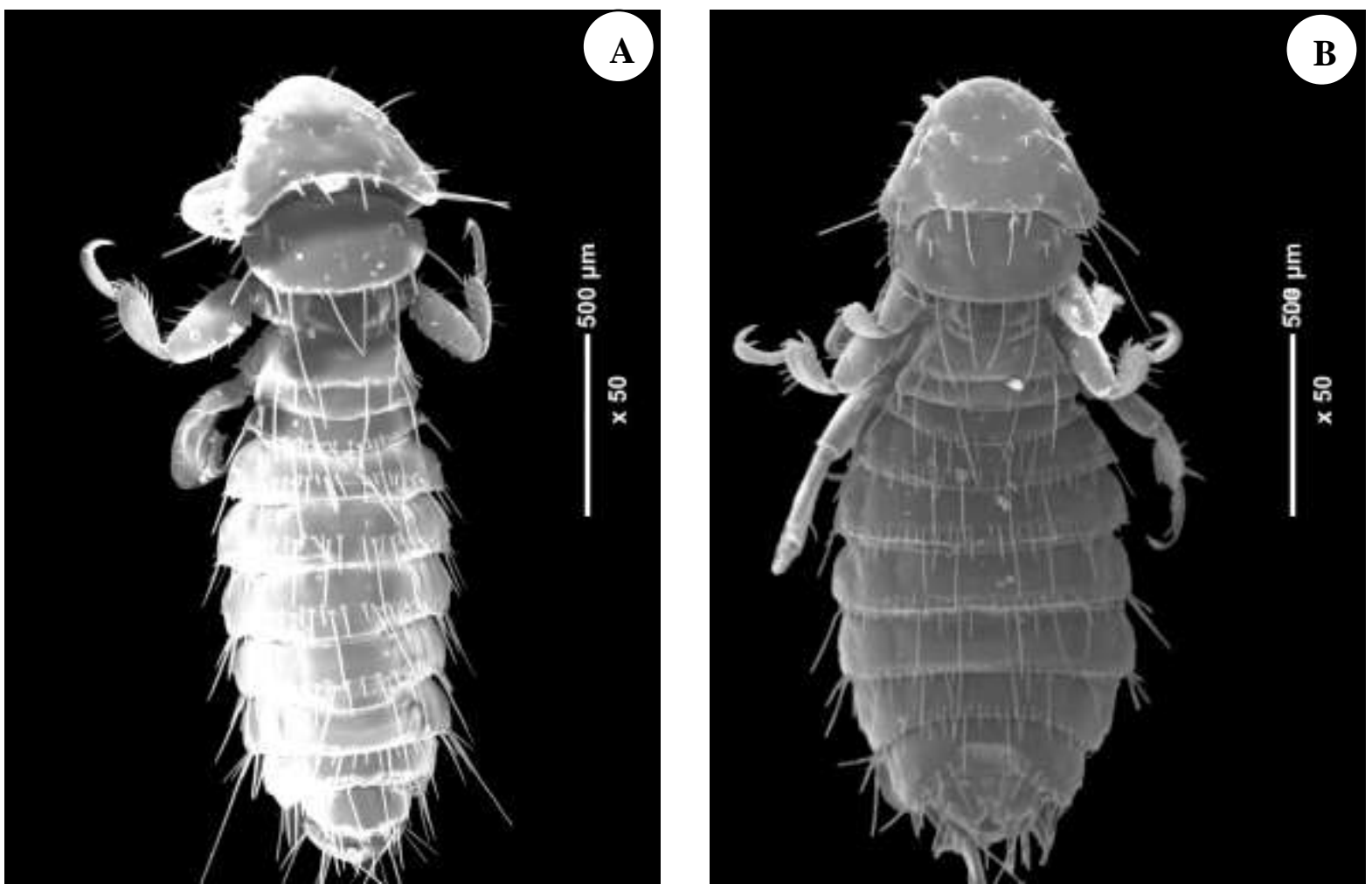

Fig 1:- SEM photograph of the adult H. spiniger (A- Male, B-Female).

\section{Acknowledgements:-}

A deep sense of gratitude is expressed to the Director of Zoological Survey of India, Kolkata for providing opportunity and facilities for the execution of this work. Thanks are also expressed to the Officer-In-Charge, Dr. Anil Mohapatra Scientist ' $D$ ' for extending his valuable and affectionate guidance, for suggesting the problem and providing all kinds of facilities. 


\section{References:-}

1. Bermudez SC, Miranda RC. Distribution of ectoparasites of Canis lupus familiaris L. Carnivora: Canidae from Panama La. Revista MVZ Cordoba, 2011; 16 .1: 2274-2282.

2. Emerson KC, Price RD. Mallophaga of Venezuelan mammals. Brigham Young University Science Bulletin Biological Series, 1975; 20(3):1-77.

3. Jittapalapong SA, Sangvaranond T, Inpankaew N, Pinyopanuwat W, Chimnoi C, Kengradomkij, Wongnakphet S. Ectoparasites of stray cats in Bangkok metropolitan areas. Thailand Kasetsart Journal. Natural Science, 2008; 42: 71-75.

4. Keler S. A revision of the Australian Boopiidae.Insecta: Phthiraptera with notes on the Trimenoponidae Australian Journal of Zoology 6. Supplement Series, 1971; 1-126.

5. Norhidayu S, Mohd. ZSN, Jeffery J, Lewis JW. The dog louse Heterodoxus spiniger from stray cats in Penang Malaysia. Tropical Biomedicine, 2012; 29 (2): 301-303.

6. Plomley NJB. Notes on the systematics of two species of Heterodoxus spiniger (Mallophaga: Boopide). Pap. Proc. Roy Soc, 1939; 19-26.

7. Price MA and Graham O H. Chewing and Sucking Lice as Parasites of Mammals and Birds. US Department of Agriculture Technical Bulletin, 1997; 1849: 7-11.

8. Price RD, Hellenthal RA, Palma RL, Johnson KP and Clayton DH. The chewing lice:World checklist and biological overview. Illinois Natural History Survey special Publication, 2003; 24: X+501 pp.

9. Roberts LJ, Janovy J. Foundation of Parasitology Sixth Edition Boston: Mc Graw-Hill Inc. 2000.

10. Sultan K, Khalafalla RE. First records of chewing louse Heterodoxus spiniger. Insecta: Phthiraptera: Boopidae. on stray dogs from northern region of Egypt. Tropical Biomedicine, 2014. 31.2.:378-380.

11. Torres FD, Figueredo L. Heterodoxus spiniger. Enderlein 1909 on domestic dogs. Canis familiaris L 1758. from the city of Recife Pernambuco State Brazil. Brazilian Journal of Veterinary Research and Animal Science, 2007; 44 (2): 77-80.

12. Troyo A O, Calderon-Arguedas G, Alvarado LE, Vargas-Castro, Avendano A. Ectoparasites of dogs in home environments on the Caribbean slope of Costa Rica. Revista Brasileria Parasitologia Veterinaria, 2012, 21(2): 179-183.

13. Tyagi S, Gupta N, Joshi VD, Rashmi A, Arya G, Saxena A K. The eggshell morphology of Heterodoxus spiniger infesting dog Canis familiaris. Boopiidae Mallophaga. Journal of Applied and Natural Science, 2009; 1(1): 71-73.

14. Tyagi S, Rashmi A, Joshi VD, Bansal N, Saxena AK. Prevalence of dog louse Heterodoxus spiniger. Indian Veterinary Journal, 2011; 88:76-77.

15. Venzal JM, Radcenco P, Rocca H, Sequeira C. First record of the louse Heterodoxus spiniger. Phthiraptera: Amblycera: Boopidae. Parasitizing dogs in Uruguay. Veterinaria Montevideo, 2012; 48 (187): 21-23.

16. Yoshizawa K, Johnson KP. Morphology of male genitalia in lice and their relatives and phylogenetic implications. Systematic Entomology, 2006; (31): 350-361.

17. Zlotorzycka J, Modrzejewska M. Morphologic features with particular regard to surface ultrastructure of Docophoroides brevis (Docophoroididae: Mallophaga). Wiadomosci Parazytologiczne, 1992; 38 (1-2):43-50.

18. Zlotorzycka JM, Modrzejewska, Saxena AK. Heterodoxus spiniger. Boopiidae Mallophaga from Canis familiaris from India in the light and scanning electron microscopes. Wiadomosci Parazytologiczne, 1995; 41(4):455-462. 